\title{
Enhanced Production of Monocyte Chemoattractant Protein-1 in Rheumatoid Arthritis
}

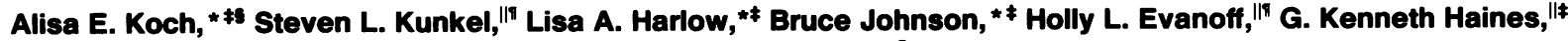 \\ Marie D. Burdick, ${ }^{* \Uparrow}$ Richard M. Pope, ${ }^{* * \$}$ and Robert M. Strieter ${ }^{* \|}$ \\ Departments of * Medicine and ${ }^{\|}$Pathology, ${ }^{\ddagger}$ Northwestern University Medical School, and ${ }^{\S}$ Veteran's Administration Lakeside Medical \\ Center, Chicago, Illinois 60611; and "The University of Michigan Medical Center, Ann Arbor, Michigan 48109
}

\begin{abstract}
Cells within the synovial tissue may recruit mononuclear phagocytes into the synovial fluid and tissues of arthritic patients. We investigated the production of the chemotactic cytokine monocyte chemoattractant protein-1 (MCP-1) using sera, synovial fluid, synovial tissue, as well as macrophages and fibroblasts isolated from synovial tissues from 80 arthritic patients. MCP1 levels were significantly higher $(P<0.05)$ in synovial fluid from RA patients (mean $25.5 \pm 8.1 \mathrm{ng} / \mathrm{ml}$ [SE]) compared to synovial fluid from osteoarthritis (OA) patients $(0.92 \pm 0.08)$, or from patients with other arthritides (2.9 \pm 1.5$)$. MCP-1 levels in RA sera $(8.44 \pm 2.33)$ were significantly greater than MCP-1 in normal sera $(0.16 \pm 0.06)$. The quantities of $R A$ synovial fluid IL-8, which is chemotactic for neutrophils and lymphocytes, and MCP-1 were strongly positively correlated ( $P$ $<0.05)$. To examine the cellular source of MCP-1, RA synovial tissue macrophages and fibroblasts were isolated. Synovial tissue fibroblasts did not express MCP-1 mRNA, but could be induced to produce MCP-1 by stimulation with either IL-1 $\beta$, tumor necrosis factor-alpha (TNF- $\alpha$ ), or LPS. In contrast, unlike normal peripheral blood monocytes or alveolar macrophages, RA synovial tissue macrophages constitutively expressed MCP-1 mRNA and antigen. Immunohistochemical analysis of synovial tissue showed that a significantly greater percentage of $R A$ macrophages $(50 \pm 8 \%)$ as compared to either OA macrophages $(5 \pm 2)$ or normal macrophages $(1 \pm 0.3)$ reacted with anti-MCP-1 antibodies. In addition, the synovial lining layer reacted with MCP-1 in both RA and OA synovial tissues. In contrast, only a minority of synovial fibroblasts (18 $\pm 8 \%$ ) from RA synovium were positive for immunolocalization of MCP-1. These results suggest that synovial production of MCP-1 may play an important role in the recruitment of mononuclear phagocytes during inflammation associated with RA and that synovial tissue macrophages are the dominant source of this cytokine. (J. Clin. Invest. 1992. 90:772-779.) Key words: mononuclear phagocytes • chemotaxis • cytokine • synovium • synovial fluid
\end{abstract}

\section{Introduction}

Synovial tissue macrophages are important in mediating RA joint destruction, mainly due to their ability to process antigen

Address correspondence to Alisa E. Koch, M. D., Northwestern University Medical School, Department of Medicine, 303 East Chicago Avenue, Ward Building 3-315, Chicago, IL 60611.

Received for publication 17 January 1992.

The Journal of Clinical Investigation, Inc.

Volume 90, September 1992, 772-779 and release a variety of cytokines, including IL-1, $-6,-8$, transforming growth factor-beta, tumor necrosis factor- $\alpha$ (TNF$\alpha),{ }^{1}$ and the colony-stimulating factors, macrophage colonystimulating factor-1 and granulocyte-macrophage colony-stimulating factor (GM-CSF) (1-15). In addition, macrophages mediate the fibroproliferative phase of RA by producing angiogenic activity $(16,17)$. Furthermore, synovial macrophages may influence synovial fibroblasts to liberate the cytokines IL$6,-8$, and GM-CSF, via TNF- $\alpha$ and IL-1, thus creating an operative cytokine network in the joint.

The mechanism by which synovial monocytes are recruited into synovial tissues and fluids has not been fully elucidated. Synovial tissue blood vessel endothelial cells express adhesion molecules like vascular cell adhesion molecule-1, which can mediate the binding of monocytes to blood vessels $(18,19)$. In addition, it is likely that chemoattractants released by cells in the synovial tissue and fluid recruit mononuclear phagocytes into the joint.

Recently a chemotactic cytokine, termed monocyte chemoattractant protein-1 (MCP-1) has been identified (20-23). This chemotaxin is expressed by a variety of cell types, including leukocytes, smooth muscle cells, endothelial cells, fibroblasts, epithelial cells, and tumor cell lines (20, 24-32). Moreover, this cytokine appears to have selective chemotactic activity for mononuclear phagocytes. The role of this cytokine in the inflamed RA joint has, as yet, not been defined.

In this study, we demonstrated significantly greater MCP-1 levels from synovial fluids of patients with RA as compared with osteoarthritis (OA) or other inflammatory and noninflammatory arthritides. Patients with RA had increased levels of MCP-1 in their serum as compared to normal volunteers. Furthermore, levels of MCP-1 and another chemotaxin, IL-8, were strongly and positively correlated from synovial fluids and sera of RA patients. Isolated RA synovial tissue fibroblasts expressed MCP-1 mRNA and protein in response to either LPS, IL- $1 \beta$, or TNF- $\alpha$ stimulation. Isolated RA tissue macrophages constitutively expressed both MCP-1 mRNA and antigenic MCP-1. Finally, we identified MCP-1 by immunohistology in a significantly greater percentage of RA than OA synovial tissue macrophages.

\section{Methods}

Reagent preparation. Human recombinant IL- $1 \beta$ with a sp act of 30 $\mathrm{U} / \mathrm{ng}$ was a gift from The Upjohn Co. (Kalamazoo, MI). Human recombinant TNF- $\alpha$ with a sp act of $22 \mathrm{U} / \mathrm{ng}$ was a gift from Genentech (San Francisco, CA). Human recombinant MCP-1 and IL-8 were

1. Abbreviations used in this paper: GM-CSF, granulocyte macrophage colony-stimulating factor; MCP-1, monocyte chemoattractant protein-1; OA, osteoarthritis; TNF- $\alpha$, tumor necrosis factor- $\alpha$. 
purchased from Peprotech, Inc. (Rocky Hill, NJ). Lipopolysaccharide (Escherichia coli 0111; B4) was obtained from Sigma Chemical Co. (St. Louis, MO). Polyclonal antihuman IL-8 and MCP-1 were produced by immunization of rabbits with recombinant IL-8 or MCP-1 with CFA. MAb Leu-M5 (anti-CD1 1 c, p1 50,95, CR4 receptor) detects monocytes and macrophages (Becton Dickinson \& Co., Mountain View, CA) as does mAb HAM56 (Enzo Biochem Inc., New York, NY). MAb FVIII detects Factor VIII-related antigen present on endothelial cells (Dakopatts, Carpinteria, CA).

Patient population. Synovial fluids were isolated from patients with either RA, OA, or other arthritides during therapeutic arthrocentesis. Serum specimens were obtained from some of the RA patients as well as from healthy volunteers. Synovial tissue was obtained from patients undergoing total joint replacements who met the American College of Rheumatology criteria for RA or OA $(32,33)$. Normal synovial tissues were obtained from fresh autopsies. Synovial tissues from these patients were snap frozen in OCT (Miles Laboratories Inc., Elkhart, IN). Alternatively, fresh RA tissues were used for isolation of macrophages or fibroblasts (see below). All specimens were obtained with Institutional Review Board approval. Patient demographic information included synovial fluid leukocyte and differential counts.

Isolation of human RA synovial tissue fibroblasts and macrophages and preparation of conditioned media. Fresh synovial tissues were minced and digested in a solution of dispase, collagenase, and DNase, as previously described $(16-18,34)$. Synovial fibroblast cells were cultured in RPMI plus $10 \%$ FCS containing $1 \mathrm{mM}$ glutamine, $25 \mathrm{mM}$ Hepes, $100 \mathrm{U} / \mathrm{ml}$ penicillin, $100 \mathrm{ng} / \mathrm{ml}$ streptomycin (Gibco Laboratories, Grand Island, NY), and $1 \%$ nonessential amino acids (complete media) in 75-mm tissue culture flasks (Costar Corp., Cambridge, MA). Upon reaching confluence, the cells were passaged by brief trypsinization as previously described ( 16 ). The cells were used at passage 4 or older, at which time they were a homogenous population of fibroblastic cells. The cells were plated at a concentration of $8.8 \times 10^{4}$ cells $/$ well in 24-well plates (Costar Corp.) in $1 \mathrm{ml}$ serum-free RPMI. Various concentrations of IL- $1 \beta$, TNF- $\alpha$, or LPS in RPMI were added, and conditioned media harvested.

For isolation of synovial tissue macrophages, the tissues were minced and digested as described above. The resultant single-cell suspensions were fractionated into density-defined subpopulations by isopyknic centrifugation through continuous preformed Percoll gradients (Pharmacia Inc., Piscataway, NJ). Macrophages were enriched by adherence to fibronectin-coated collagen gels and selective trypsinization (incubation with trypsin:EDTA for 5-10 $\mathrm{min})(16,17,34,35)$. Macrophages were harvested from the collagen gels by treatment with clostridial collagenase and found to be $\geq 90 \%$ pure, as assessed by $F_{c}$ receptormediated phagocytosis of IgG opsonized sheep red blood cells, esterase staining, and staining with commercial antimacrophage mAbs (16, 17). For preparation of conditioned medium, freshly isolated macrophages were incubated in DME + gentamicin at $1 \times 10^{6}$ cells $/ \mathrm{ml}$, and supernatants collected after $24 \mathrm{~h}$.

MCP-1 ELISA. Antigenic MCP-1 was measured using a modification of a double ligand method as previously described (36). In brief, 96-well plates (Nunc, Kamstrup, Denmark) were coated with $50 \mu \mathrm{l}$ / well rabbit anti-MCP-1 $\left(3.2 \mu \mathrm{g} / \mathrm{ml}\right.$ in $0.6 \mathrm{M} \mathrm{NaCl}, 0.26 \mathrm{M} \mathrm{H}_{3} \mathrm{BO}_{4}$, and $0.08 \mathrm{~N} \mathrm{NaOH}, \mathrm{pH} 9.6$ ) for $16 \mathrm{~h}$ at $4^{\circ} \mathrm{C}$ and then washed in PBS, pH $7.5,0.05 \%$ Tween-20 (wash buffer). Nonspecific binding sites were blocked with $2 \%$ BSA in PBS $(200 \mu 1)$, and the plates incubated for 90 min at $37^{\circ} \mathrm{C}$. Plates were rinsed $(3 \times)$ with wash buffer and diluted (neat, 1:5, and 1:10) test sample $(50 \mu \mathrm{l})$ in duplicate was added, followed by incubation for $1 \mathrm{~h}$ at $37^{\circ} \mathrm{C}$. Plates were washed $(4 \times)$ and 50 $\mu \mathrm{l} /$ well biotinylated rabbit anti-MCP-1 $(6 \mu \mathrm{g} / \mathrm{ml}$ in PBS, $\mathrm{pH} 7.5$, $0.05 \%$ Tween-20, $2 \%$ FCS $)$ added for $45 \mathrm{~min}$ at $37^{\circ} \mathrm{C}$. Plates were washed $(4 \times)$, streptavidin-peroxidase conjugate $(100 \mu \mathrm{g} / \mathrm{ml})$ (Dako patts) added, and the plates were incubated for $30 \mathrm{~min}$ at $37^{\circ} \mathrm{C}$. The plates were washed $(3 \times)$ and $100 \mu \mathrm{l}$ chromogen substrate $(0.67 \mathrm{mg} / \mathrm{ml}$ orthophenylenediamine dichloride) (Dako patts) added. The plates were incubated at $25^{\circ} \mathrm{C}$ for $6 \mathrm{~min}$, and the reaction terminated with 50 $\mu \mathrm{l} /$ well of $3 \mathrm{M} \mathrm{H}_{2} \mathrm{SO}_{4}$ solution in wash buffer plus $2 \% \mathrm{FCS}$. Plates were read at $490 \mathrm{~nm}$ in an ELISA reader. Standards were $1 / 2$ log dilutions of recombinant $\mathrm{MCP}-1$ from $1,000 \mathrm{ng} / \mathrm{ml}$ to $1 \mathrm{pg} / \mathrm{ml}(50 \mu \mathrm{l} /$ well $)$. The ELISA consistently detected MCP-1 concentrations $>0.05 \mathrm{ng} / \mathrm{ml}$.

$I L-8$ ELISA. Antigenic IL-8 was measured using a modification of a double ligand method as previously described using polyclonal antiIL-8 (1). The assay was standardized using human recombinant IL-8.

Northern blot analysis. Total cellular RNA was obtained from 2.5 $\times 10^{6}$ macrophages or confluent fibroblasts in $100-\mathrm{mm}$ tissue culture dishes using a modification of Chirgwin et al. and Jonas et al. (37-39). Briefly, cells were scraped into a solution containing $25 \mathrm{mM}$ Tris, $\mathrm{pH}$ 8.0, 4.2 M guanidine isothiocyanate, $0.5 \%$ Sarkosyl, and 0.1 M 2-mercaptoethanol. After homogenization, the suspension was added to a solution containing an equal volume of $100 \mathrm{mM}$ Tris, $\mathrm{pH} 8.0,10 \mathrm{mM}$ EDTA, and $1 \%$ SDS. The mixture was then extracted with chloroformphenol and chloroform-isoamyl alcohol. The RNA was alcohol precipitated and the pellet dissolved in diethylpyrocarbonate-treated $\mathrm{H}_{2} \mathrm{O}$. Total RNA was separated by Northern analysis using formaldehyde, $1 \%$ agarose gels, transblotted onto nitrocellulose, baked, prehybridized, and hybridized with a ${ }^{32} \mathrm{P}-5^{\prime}$ end-labeled oligonucleotide probe. A 30 mer oligonucleotide probe was synthesized using the published cDNA sequence for human-derived MCP-1 (20). The probe was complementary to nucleotides 256-285 and had the sequence 5'-TTG-GGT-TTGCTT-GTC-CAG-GTG-GTC-CAT-GGA-3'. Blots were washed and autoradiographs were quantitated using laser densitometry (Ultrascan XS; LXB Instruments, Inc., Houston, TX). Equivalent amounts of total RNA/gel were assessed by monitoring $28 \mathrm{~s}$ and $18 \mathrm{~s}$ rRNA.

Bioassay for chemotactic activity for monocytes. Chemotaxis of monocytes was performed as previously described (24). Normal human mononuclear cells were obtained from peripheral blood by FicollHypaque density gradient centrifugation. Monocytes were suspended in HBSS with calcium and magnesium (Gibco Laboratories) at $3 \times 10^{6}$ cells $/ \mathrm{ml}$ with $>95 \%$ viability by trypan blue exclusion. In brief, $150 \mu \mathrm{l}$ of synovial fluid or synovial tissue macrophage conditioned medium which was diluted 1:1 with HBSS, $10^{-8}$ M FMLP (Sigma Chemical Co.), or HBSS alone were placed in duplicate bottom wells of a blindwell chemotaxis chamber. A 5- $\mu \mathrm{m}$ pore size polyvinylpyrrolidone-free polycarbonate filter (Nuclepore Corp., Pleasanton, CA) was placed in the assembly and $250 \mu \mathrm{l}$ of monocyte suspension placed in each of the top wells. Chemotaxis chambers were incubated at $37^{\circ} \mathrm{C}$ in humidified $95 \%$ air $/ 5 \% \mathrm{CO}_{2}$ for $2 \mathrm{~h}$. The filters were removed, fixed in absolute methanol, and stained with $2 \%$ toluidine blue (Sigma Chemical Co.). Monocytes that had migrated through to the bottom of the filter were counted in 10 high power fields $(\times 1,000)$.

Immunoperoxidase staining. $4-\mu \mathrm{m}$ sections of frozen tissues were cut, and immunoperoxidase stained using an avidin-biotin technique (Vector Laboratories, Burlingame, CA) $(34,40-44)$. Slides, air dried for $2-16 \mathrm{~h}$, were fixed in cold acetone for $20 \mathrm{~min}$. Endogenous peroxidase activity was quenched by incubating the slides for $30 \mathrm{~min}$ in $0.3 \%$ hydrogen peroxide in methanol. All subsequent incubations were performed for $15 \mathrm{~min}$ at $37^{\circ} \mathrm{C}$ in a moist chamber. The tissue sections were pretreated with $50 \mu$ l diluted normal horse serum ( $135 \mu$ l horse serum in $10 \mathrm{ml} 1 \%$ PBS-BSA), incubated with either rabbit anti-human MCP-1, preimmune rabbit serum, mAb Leu-M5, mAb HAM56, or control $\mathrm{mAb}$ and washed $(2 \times)$. The slides were incubated with a 1:400 dilution of anti-mouse biotinylated antibody in PBS-BSA, washed $(2 \times)$ with PBS, incubated with avidin/biotinylated horseradish peroxidase complex, and washed with PBS $(2 \times)$. Slides were then stained with diaminobenzidine tetrahydrochloride substrate for $5 \mathrm{~min}$ at room temperature, rinsed in tap water for 2 min, counterstained with Harris' hematoxylin, and dipped in saturated lithium carbonate solution for bluing. Serial tissue sections were examined to determine the percentage of each cell type expressing antigenic MCP-1 $(18,34,43)$.

Cytospin preparations of isolated RA synovial tissue macrophages were made using $10^{5}$ cells per slide in a cytospin (Shandon I; Shandon Inc., Swickley, PA). Slides were stained using immunohistochemistry as described above.

Statistical analysis. Statistical analysis was performed using analysis of variance $(45,46) . P$ values $<0.05$ were considered significant. 


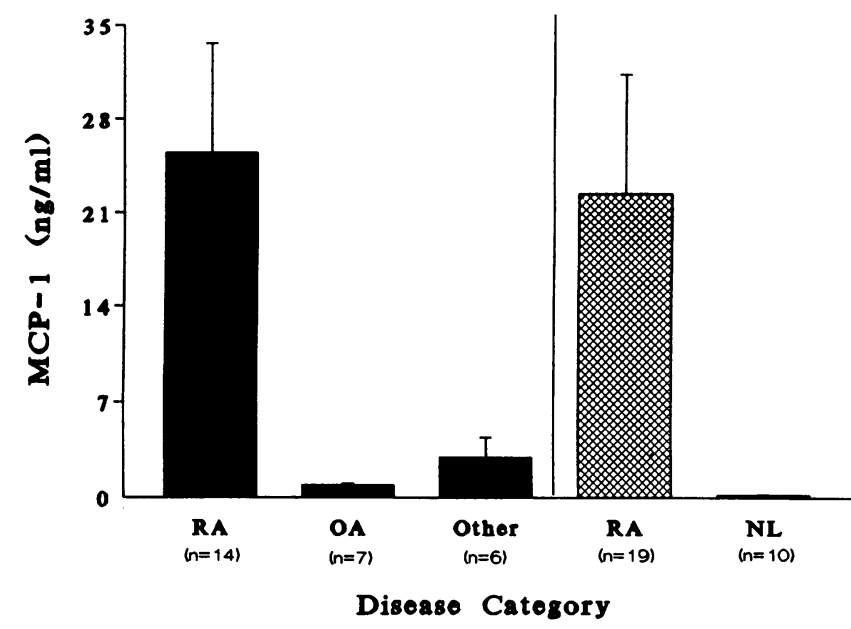

Figure 1. Antigenic MCP-1 levels in synovial fluid from various arthritides as well as RA and normal serum. Results represent the mean \pm SE. Six replicate determinations per patient were performed. $\mathrm{N}$ represents the number of patients studied. $\boldsymbol{\square}$; synovial fluid; $\boldsymbol{\square}$, serum.

\section{Results}

$M C P-1$ is elevated in both $R A$ synovial fluid and sera. In initial experiments, MCP-1 was measured by ELISA using samples obtained from 27 patients (Fig. 1). The patients with RA had the greatest levels of MCP-1 (mean $25.5 \pm 8.1 \mathrm{ng} / \mathrm{ml}$ ). OA patients as compared with RA patients had significantly less MCP-1 in their synovial fluids $(0.92 \pm 0.08 \mathrm{ng} / \mathrm{ml}, P<0.05)$. Patients with other forms of inflammatory and noninflammatory arthritis including polymyositis, Reiter's syndrome, chronic lymphocytic leukemia, and mixed connective tissue disease had a mean of $2.9 \pm 1.5 \mathrm{ng} / \mathrm{ml}$ of synovial fluid MCP-1, which was also significantly less than patients with RA ( $P$ $<0.05)$.

To determine whether peripheral blood from patients with RA also contained significant quantities of MCP-1 compared to normal volunteers, serum MCP-1 levels were determined by ELISA using 19 RA samples (Fig. 1). Serum levels of RA $\mathrm{MCP}-1$ ranged from $<0.08 \mathrm{ng} / \mathrm{ml}$ to $179.2 \mathrm{ng} / \mathrm{ml}$ (mean $22.4 \pm 8.9$ ). In contrast normal sera obtained from 10 volun-

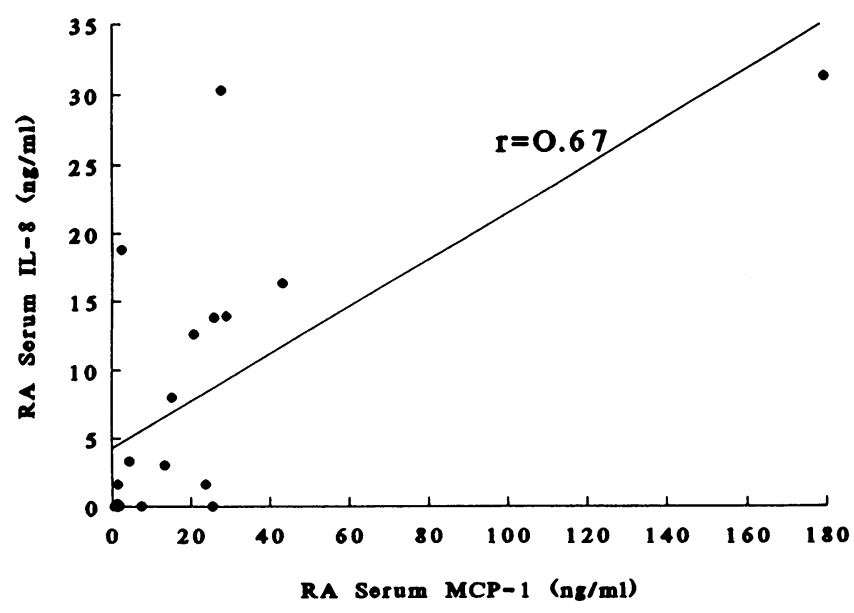

Figure 2. Positive correlation between serum antigenic MCP-1 and IL-8.

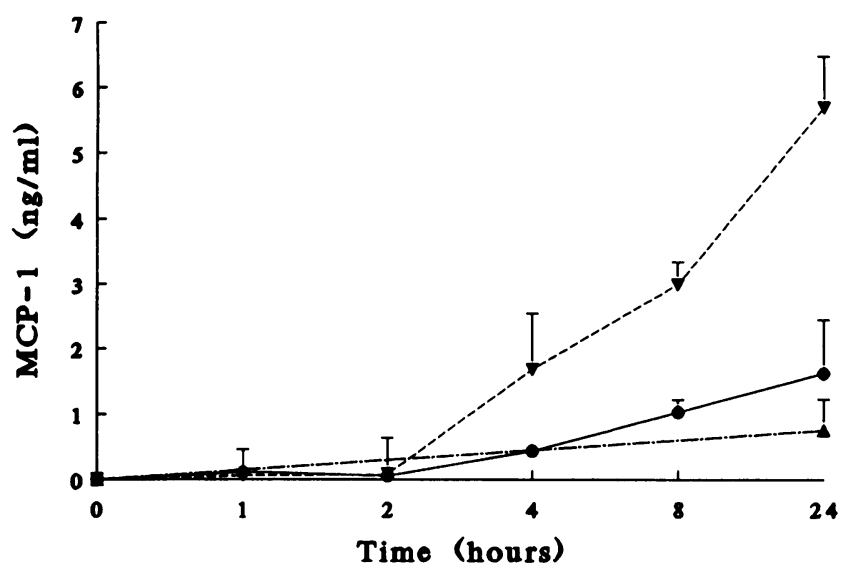

Figure 3. Time-dependent generation of synovial fibroblast MCP-1 by LPS, and IL- $1 \beta$ stimulation. RA fibroblasts $\left(8.8 \times 10^{4}\right.$ cells $/$ well $)$ were cultured in serum-free RPMI for various time periods. Results represent the mean \pm SE from two patient samples. Six replicates of each sample were assayed. $-\bullet-$, LPS $(1 \mu \mathrm{g} / \mathrm{ml}) ;-\nabla-$, IL- $1 \beta$ $(20 \mathrm{ng} / \mathrm{ml}) ;-\Delta-$, nontreated.

teers contained significantly less MCP-1 $(<0.05$ to $0.72 \mathrm{ng} /$ ml) (mean $0.16 \pm 0.06, P<0.05$ ). The high levels of MCP-1 present in the RA sera were not attributable to rheumatoid factor in these samples, since there was no correlation between rheumatoid factor positivity (using rabbit $\mathrm{IgG}$ ) and MCP-1 levels.

Positive correlation between synovial fluid and serum MCP- 1 and IL-8 levels. Since cells of the synovial milieu might concomitantly recruit both monocytes and other inflammatory leukocytes, we wished to determine whether those patients who produced large quantities of MCP-1 also produced large quantities of IL-8. ELISA assays were performed on the sera and synovial fluids of arthritic patients to determine the quantities of IL-8 produced. Comparing RA synovial fluid MCP-1 and IL-8 levels, a significant positive correlation $(r=0.57, P$
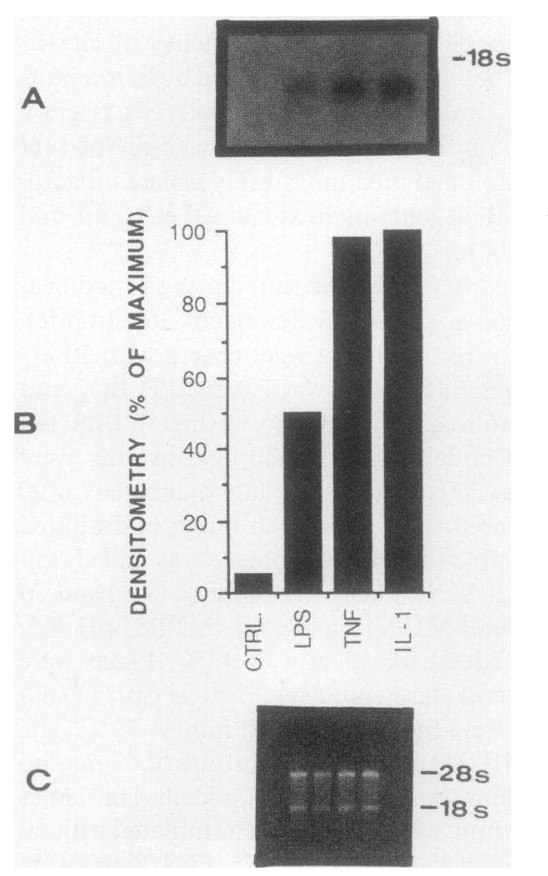

Figure 4. (A) Inducible RA fibroblast MCP-1 gene expression. Representative Northern blot of RA synovial fibroblasts which were cultured for $8 \mathrm{~h}$ in serumfree media with or without LPS $(1 \mu \mathrm{g} / \mathrm{ml})$, IL- $1 \beta(20 \mathrm{ng} / \mathrm{ml})$, or TNF- $\alpha(20 \mathrm{ng} / \mathrm{ml})$. MCP-1 message was absent without stimulation. Ctrl, control untreated fibroblasts. $(B)$ Laser densitometry of MCP-1 mRNA. (C) $18 \mathrm{~S}$ and $28 \mathrm{~S}$ rRNA to demonstrate equivalent loading of RNA in $A$. 


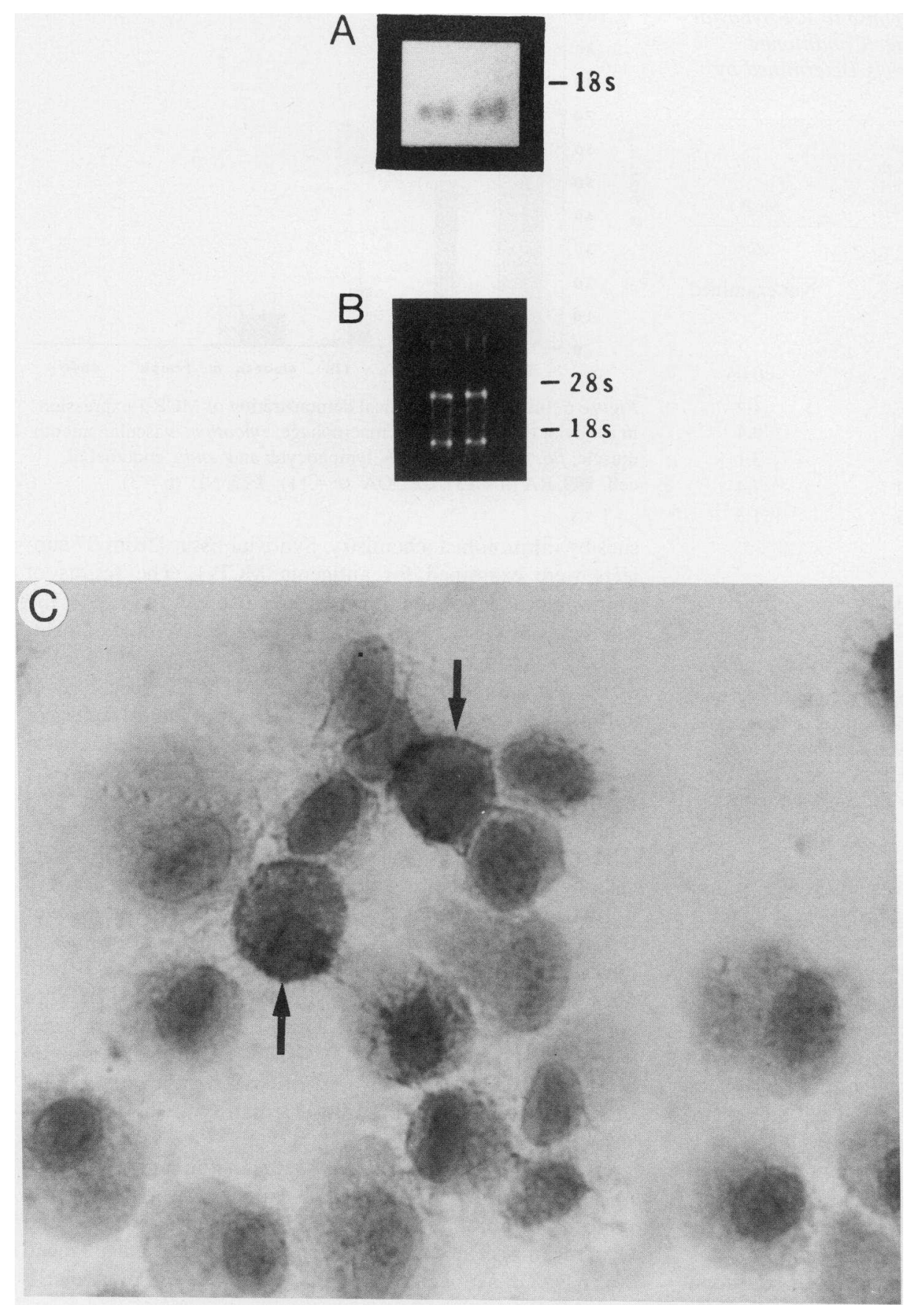

Figure 5. (A) A representative Northern blot showing MCP-1 gene expression from freshly isolated RA synovial tissue macrophages from two patients. $(B) 18 \mathrm{~S}$ and $28 \mathrm{~S}$ rRNA demonstrating equivalent loading of total RNA in $A$. ( $C$ ) Immunoperoxidase stained cytocentrifuge preparation of freshly isolated RA synovial macrophages showing MCP-1 antigen expression (arrows) $(\times 816)$.
$<0.05$ ) was found. Similarly, synovial fluid from other arthritides contained MCP-1 and IL-8 levels which were also strongly positively correlated $(r=0.96, P<0.05)$. RA serum MCP-1 and IL-8 levels were correlated, implying a parallel relationship between the amounts of chemotactic cytokines released specific for differing leukocyte populations in this disorder (Fig. 2, $r=0.67, P<0.05$ ).

$R A$ synovial fibroblast production of $M C P-1$. To ascertain whether cellular constituents of the synovial tissue were able to produce MCP-1 in vitro, isolated cell populations from RA synovial tissues were examined. RA fibroblast cells appeared to be a homogenous cellular population of cells with elongated processes. No rounded cells were present. Moreover, RA fibroblasts were esterase negative, and nonreactive with the antima- crophage mAbs Leu-M5 and HAM 56, excluding the presence of contaminating macrophages. Cytocentrifuge preparations of fibroblasts did not react immunohistochemically with mAb FVIII, excluding the presence of contaminating endothelial cells. LPS induced fibroblast MCP-1 release at concentrations of $100 \mathrm{ng} / \mathrm{ml}$ and above. In contrast, as little as $0.02 \mathrm{ng} / \mathrm{ml}$ IL- $1 \beta$ or TNF- $\alpha$ induced fibroblast MCP- 1 release. Maximal stimulatory concentrations of IL- $1 \beta$ and TNF- $\alpha$ were $0.2 \mathrm{ng} /$ $\mathrm{ml}$ and $20 \mathrm{ng} / \mathrm{ml}$, respectively. Time-dependent generation of MCP-1 is shown in Fig. 3. LPS-induced fibroblast MCP-1 increased steadily over $24 \mathrm{~h}$ as did IL-1- $\beta$ induced MCP-1. While LPS induced $1.62 \pm 0.8 \mathrm{ng} / \mathrm{ml}$ (SE) MCP-1, IL- $1 \beta$ induced $5.7 \pm 0.78 \mathrm{ng} / \mathrm{ml} \mathrm{MCP}-1$. Nonstimulated fibroblasts released $0.29 \pm 0.78 \mathrm{ng} / \mathrm{ml} \mathrm{MCP}-1$. Fibroblast MCP-1 gene expression 
Table I. Chemotaxis of Monocytes in Response to RA Synovial Fluids and RA Synovial Tissue Macrophage Conditioned Medium Compared to MCP-1 Protein Levels Determined by ELISA Assay

\begin{tabular}{lcc}
\hline & $\begin{array}{c}\text { Mean } \\
\text { cells/high } \\
\text { power field } \\
(\times 1,000)\end{array}$ & MCP-1 \\
\hline FMLP $\left(10^{-8} \mathrm{M}\right)$ & & Ng/ml \\
Macrophage-conditioned medium & 44 & Not examined \\
Patient number & & \\
1 & 15 & $<0.05$ \\
2 & 17 & 2.3 \\
3 & 24 & 0.4 \\
4 & 29 & 3.1 \\
5 & 19 & 7.4 \\
6 & 35 & 1.3 \\
Synovial fluid & & \\
Patient number & & 10.7 \\
1 & 23 & 1.4 \\
2 & 52 & \\
\hline
\end{tabular}

RA synovial fluids and synovial tissue macrophage-conditioned media were assayed for their ability to induce chemotaxis of monocytes. The results represent analysis of 10 high power fields per sample. Negative control migration in response to HBSS = mean of five cells/high power field. MCP-1 was assayed by ELISA (see Methods).

was absent in nonstimulated RA fibroblasts, but readily inducible upon LPS $(1 \mu \mathrm{g} / \mathrm{ml}), \mathrm{IL}-1 \beta(20 \mathrm{ng} / \mathrm{ml})$, or TNF- $\alpha(20$ $\mathrm{ng} / \mathrm{ml}$ ) treatment of cells (Fig. 4 ).

$R A$ synovial fluid and macrophage generated monocyte chemotactic activity. We then determined whether RA synovial fluids and conditioned medium from synovial tissue macrophages produced biologically active chemotactic activity for monocytes. Chemotactic activity for normal human peripheral blood monocytes was detected in the RA synovial fluids examined ( Table I). Conditioned medium from nonstimulated macrophages obtained from six patients also contained chemotactic activity for monocytes. Measurable antigenic MCP-1 ranged from $<0.05$ to $7.4 \mathrm{ng} / \mathrm{ml}$ in these samples. The amounts of chemotactic activity for monocytes and antigenic MCP-1 did not corrèlate, implying the presence of additional chemotactic factors for monocytes in the synovial fluids and in the RA synovial tissue macrophage supernatants.

Synovial tissue macrophage production of $M C P-1$. To determine if RA synovial tissue macrophages constitutively expressed MCP-1, MCP-1 gene expression was determined using isolated RA synovial tissue macrophages (Fig. 5). In contrast to RA fibroblasts, RA macrophages did not require exogenous stimulation to express MCP-1 mRNA. To confirm macrophage constitutive MCP-1 production, macrophages were freshly isolated from the synovial tissues of RA patients, cytospun, and stained for immunolocalization of MCP-1. Fig. $5 c$ shows RA synovial tissue macrophage MCP-1 antigen expression.

Immunohistochemical localization of MCP-1 to RA synovial tissue macrophages. To immunolocalize the cells responsible for MCP-1 production in vivo, we examined synovial tis-

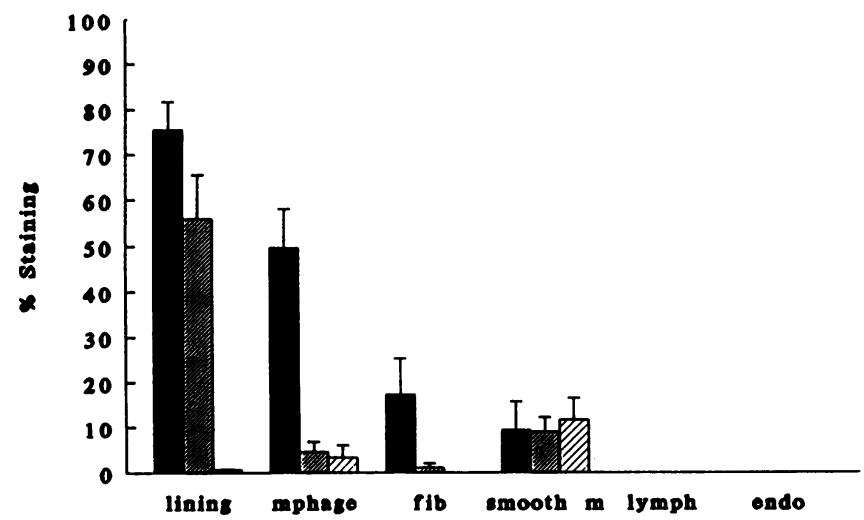

Figure 6. Immunohistochemical demonstration of MCP-1 expression in synovial tissues. Mphage, macrophage; smooth $m$, vascular smooth muscle; fib, fibroblast; lymph, lymphocyte; and endo, endothelial cell. $\square$, RA $(n=13)$; $\mathbb{E}$, OA $(n=11)$;

sues by immunohistochemistry. Synovial tissues from 27 subjects were examined for antigenic MCP-1. The results of immunolocalization are shown in Figs. 6 and 7. In general, the RA synovial tissues had higher inflammatory scores (mean $2.4 \pm 0.2$ ) as compared to either the OA tissues (mean 1.5 \pm 0.2 ) or the normal tissues (mean 1.0$)(18,44)$. The specificity of anti-MCP-1 reactivity with tissues was confirmed by the use of nonimmune serum as well as preadsorbtion with recombinant human MCP-1. The MCP-1 positive cells were located in the macrophage-rich synovial lining layer, in both RA and OA synovial tissues. MCP-1 immunolocalized to a mean of $76 \pm 6 \%$ of the RA lining cells (Fig. $7 A$ ) and $60 \pm 10 \%$ of the OA lining cells (Fig. $7 \mathrm{~B}$ ), but only to $1 \pm 0.3 \%$ of the lining cells found in normal synovial tissues (Fig. $7 D)(P<0.05$ for either RA or OA compared to normal). RA synovial tissue macrophages located in the subsynovial areas also expressed MCP-1, with $50 \pm 8 \%$ of macrophages being MCP-1 positive (Fig. $7 C$ ). In contrast, only $5 \pm 2 \%$ of the OA Leu-M 5 positive macrophages were MCP-1 positive $(P<0.05)$ (Fig. 7$)$. Similarly, RA macrophage antigenic MCP-1 expression was significantly greater than the expression found in normal synovial tissues ( $P$ $<0.05)$.

As compared to the reactivity of the majority of RA macrophages with anti-MCP-1, MCP-1 expression was found in a minority of fibroblasts from both RA (mean of $18 \pm 8 \%$ ) and OA (mean of $9 \pm 3 \%$ ). In addition, a small percentage (mean $9.4 \pm 6.3 \%$ ) of synovial tissue blood vessel smooth muscle cells were MCP-1 positive.

\section{Discussion}

MCP-1 is a 76-amino acid basic protein with selective chemotactic activity for mononuclear phagocytes $(23,47)$. MCP-1 exists in two forms: MCP- $1 \alpha$, with a mol wt of 13,000 , and MCP-1 $\beta$, with a mol wt of $15,000(20,47)$. These two forms of MCP-1 are functionally identical, differing only by the extent of posttranslational modification. MCP-1 belongs to a supergene family that includes LD78, ACT-2, RANTES, and I-309 (48).

The role of MCP-1 in the inflamed RA joint may be the recruitment of mononuclear phagocytes. There are a variety of chemotactic factors which may attract mononuclear phagocytes in the RA joint. These include thrombin, C5a, platelet 

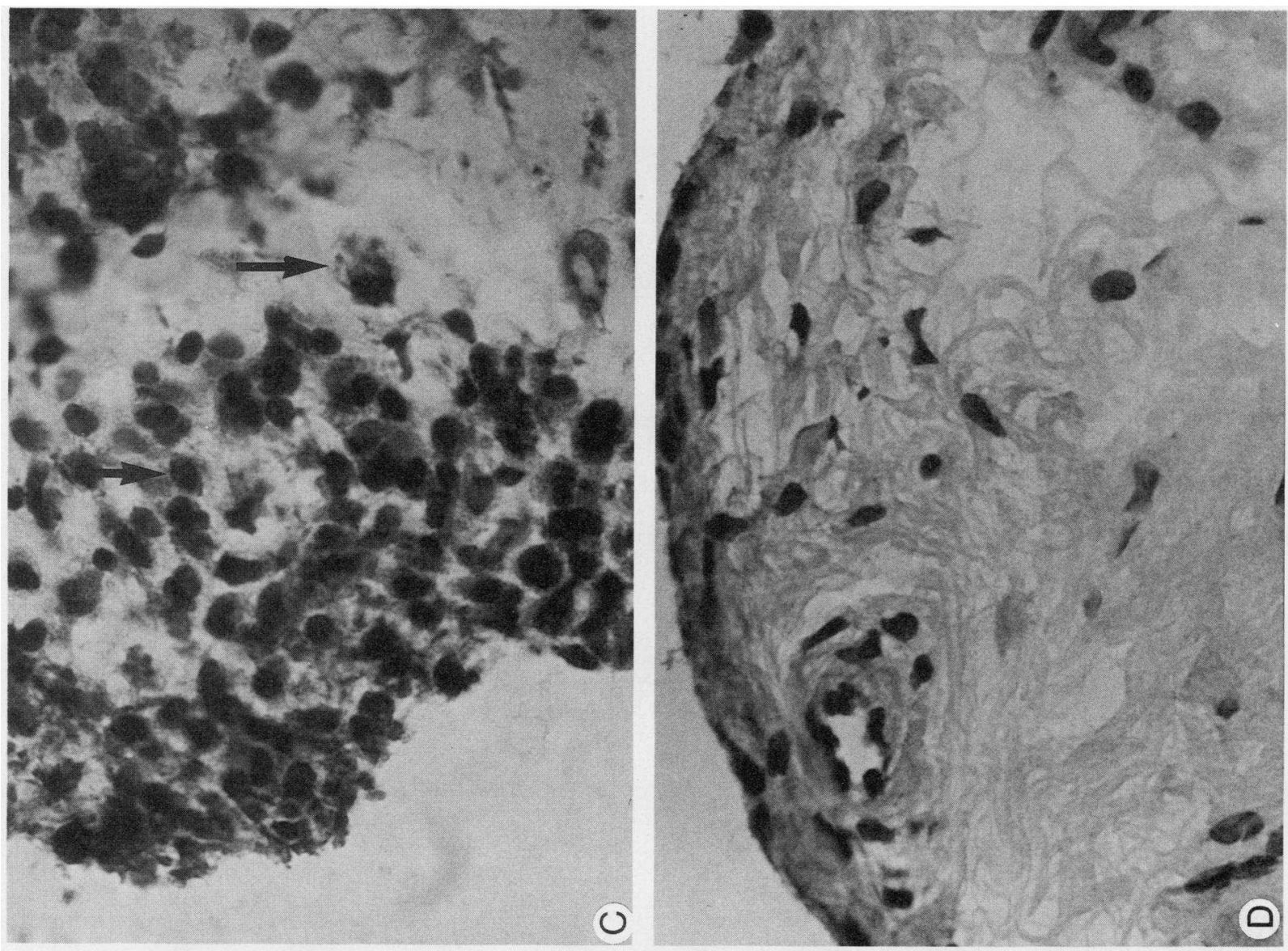

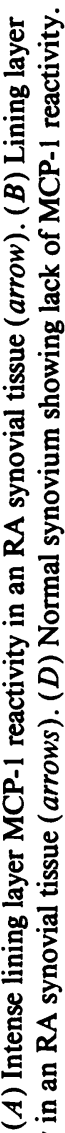
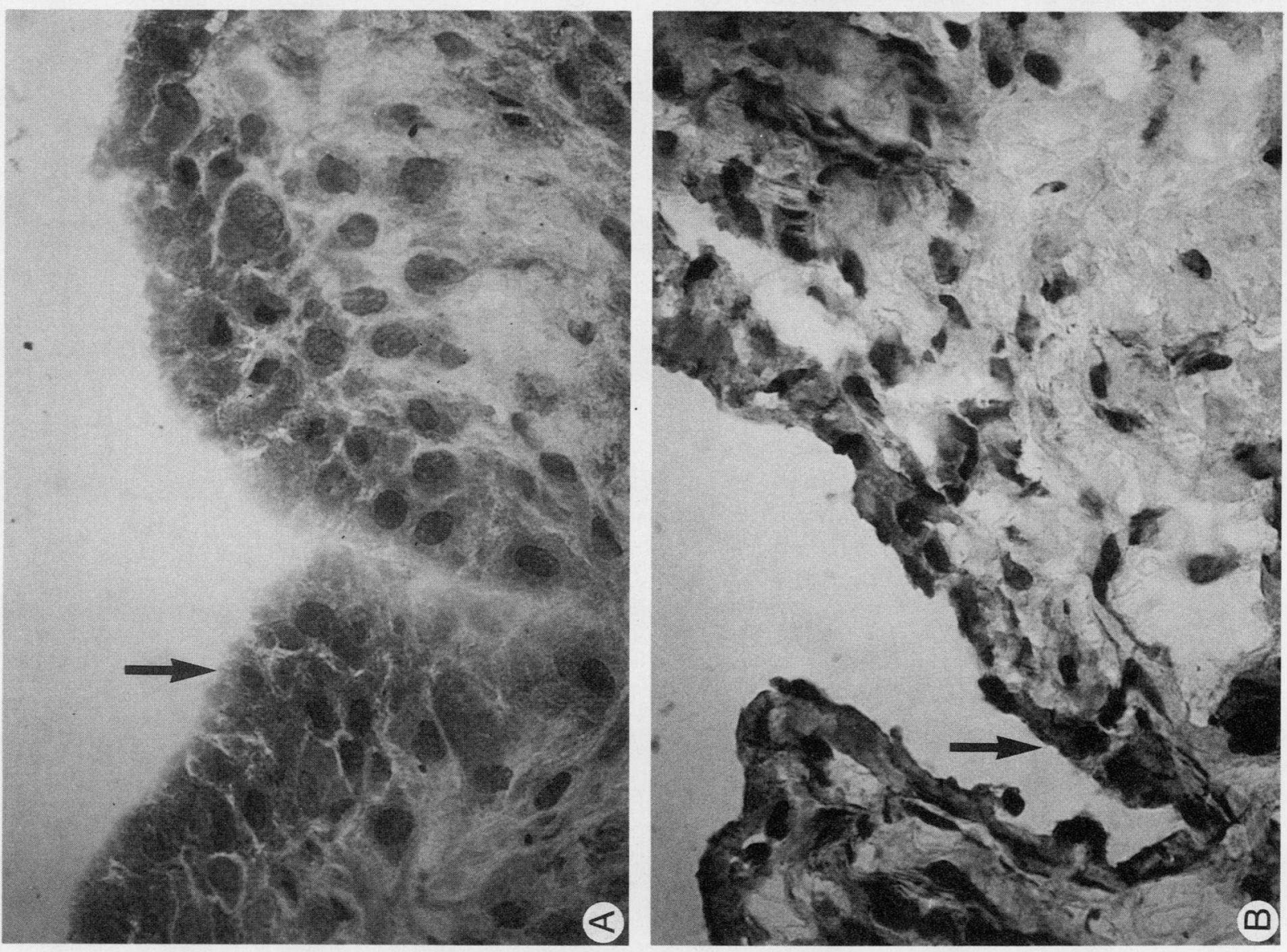

守

${ }^{x}$

通

तु

政

它

䔫

急事

돈 
activating factor, leukotriene $\mathrm{B}_{\mathbf{4}}$, lymphocyte-derived chemotactic factor, and the cytokines transforming growth factorbeta, GM-CSF, and platelet-derived growth factor (PDGF) $(49,50)$. In this study, we demonstrated that the cytokine MCP-1 may also serve as a potent stimulus for recruitment of mononuclear phagocytes in RA.

We examined synovial fluids from patients with various arthritides for MCP-1. MCP-1 levels were significantly elevated in synovial fluids from patients with RA as compared to OA or other arthritides. Moreover, while the serum levels of MCP-1 were $0.16 \pm 0.06 \mathrm{ng} / \mathrm{ml}$ from normal subjects, MCP-1 RA serum levels were significantly increased $(22.4 \pm 8.9 \mathrm{ng} / \mathrm{ml}, P$ $<0.05)$.

The process of synovial inflammation likely results from the influx of a series of inflammatory cells that release a cascade of inflammatory mediators. We reasoned that synovial fluids and sera containing chemotactic factors for mononuclear phagocytes such as MCP-1 might also contain chemotactic factors for neutrophils and lymphocytes. Indeed, we found a strong positive correlation between MCP-1 and IL-8 in both synovial fluid and serum of patients with RA. These results suggested that the same factors which might upregulate production of MCP-1 also influence the production of IL-8 (1). Hence, we examined whether RA fibroblasts produced MCP-1 in response to the same agonists which upregulated production of synovial fibroblast IL-8. As described by DeMarco et al., who showed that RA synovial fibroblasts expressed MCP-1 mRNA in response to IL- 1 and TNF- $\alpha$, we demonstrated that RA fibroblasts respond to these signals as well as to LPS and produce both MCP-1 mRNA and protein (51). While RA fibroblasts spontaneously produced either nondetectable or low levels of MCP-1, TNF- $\alpha$, or IL- $1 \beta$, and to a lesser extent LPS induced increased levels of fibroblast MCP-1. These same stimuli serve as inducing agents for RA fibroblast IL-8 production. It is likely that in the inflamed RA synovium, macrophages produce IL- 1 and TNF- $\alpha$, both of which act on synovial fibroblasts to stimulate release of IL- 8 and MCP-1, which in turn selectively recruit neutrophils, lymphocytes, and mononuclear phagocytes into the joint.

While MCP-1 may be produced by a variety of cells such as blood mononuclear cells, endothelial cells, smooth muscle cells, fibroblasts, epithelial cells, and tumor cell lines, we have identified the synovial tissue macrophage as a major cell producing MCP-1 within the RA joint. Macrophages isolated from RA synovial tissues produced MCP-1 mRNA, antigenic MCP1 , and biologically active chemotactic activity for peripheral blood monocytes. In addition, we immunolocalized MCP-1 to isolated RA synovial tissue macrophages. RA macrophages constitutively produce $\mathrm{MCP}-1$ in greater numbers as compared to either OA or normal synovial tissue macrophages. Interestingly, normal human peripheral blood monocytes or alveolar macrophages do not express MCP-1 mRNA either constitutively or when stimulated with LPS (52). Perhaps, in the inflamed synovial milieu the synovial macrophage assumes a phenotype of chronic activation with subsequent inflammatory cytokine release. Indeed, MCP-1 has been shown to "activate" monocytes, causing cytostatic activity against tumor cell lines, stimulation of the leukocyte respiratory burst, and lysosomal enzyme release $(23,47)$. It may be that MCP-1 itself may function to activate newly recruited mononuclear phagocytes, hence perpetuating the inflammatory response in the RA synovial tissue.
In summary, synovial fluids from RA patients contain significantly more MCP-1 than fluids from OA patients or patients with other arthritides. RA serum MCP-1 levels were significantly elevated compared to normal serum MCP levels. There was a strong positive correlation between RA synovial fluid or serum levels of MCP-1 and IL-8. Immunohistological examination revealed that a significantly greater proportion of RA than OA or normal macrophages expressed antigenic MCP-1. RA synovial fibroblasts were induced to produce MCP- 1 mRNA and protein by IL- $1 \beta$, TNF- $\alpha$, or to a lesser degree LPS. RA macrophages constitutively produced MCP-1 mRNA and protein. These results may help elucidate the mechanism by which mononuclear phagocytes enter both the synovium and synovial fluid in RA.

\section{Acknowledgments}

We thank our colleagues, Dr. S. D. Stulberg, C. Schwartz, J. Galante, N. Rana, B. Briggs, and J. Lessard for supplying the synovial tissues. We would also like to thank Drs. Herbert Rubinstein and Frank Schmid for helpful discussions. We also wish to acknowledge the invaluable help of Dr. James Sinacore in performing statistical analysis of the data. We thank Ms. Corinne Washington for expert secretarial assistance.

This work was supported by National Institutes of Health grants AR30692 (A. E. Koch and R. M. Pope), AR41492 (A. E. Koch), HL02401 (R. M. Strieter), HL-31693 (S. L. Kunkel), an Arthritis Foundation grant (R. M. Pope), an Arthritis Foundation fellowship (A. E. Koch), Veteran's Administration Merit Reviews (A. E. Koch and R. M. Pope), and an American Lung Association research grant. R. M. Strieter is an RJR-Nabisco Research Scholar.

\section{References}

1. Koch, A. E., S. L. Kunkel, J. C. Burrows, H. L. Evanoff, G. K. Haines, R. M. Pope, and R. M. Strieter. 1991. Synovial tissue macrophage as a source of the chemotactic cytokine IL-8. J. Immunol. 147:2187-2195.

2. Wood, D. D., E. J. Ihrie, and D. Hamerman. 1985. Release of interleukin-1 from human synovial tissue in vitro. Arthritis Rheum. 28:853-862.

3. Miyasaka, N., K. Sato, M. Goto, M. Sasano, M. Natsuyama, K. Inoue, and K. Nishioka. 1988. Augmented interleukin-1 production and HLA-DR expression in the synovium of rheumatoid arthritis patients. Possible involvement in joint destruction. Arthritis Rheum. 31:480-486.

4. Wood, D. D., E. J. Ihrie, C. A. Dinarello, and P. L. Cohen. 1983. Isolation of an interleukin-1-like factor from human joint effusions. Arthritis Rheum. 26:975-983.

5. Yocum, D. E., L. Esperanza, S. Dubry, J. B. Benjamin, R. Volz, and P. Scuderi. 1989. Characteristics of tumor necrosis factor production in rheumatoid arthritis. Cell. Immunol. 122:131-145.

6. Husby, G., and R. C. Williams, Jr. 1988. Synovial localization of tumor necrosis factor in patients with rheumatoid arthritis. J. Autoimmun. 1:363-371.

7. Lipsky, P. E., L. S. Davis, J. J. Cush, and N. Oppenheimer-Marks. 1989. The role of cytokines in the pathogenesis of rheumatoid arthritis. Springer Semin. Immunopathol. 11:123-162.

8. Arend, W. P., and J. M. Dayer. 1990. Cytokines and cytokine inhibitors or antagonists in rheumatoid arthritis. Arthritis Rheum. 33:305-315.

9. Dayer, J.-M., B. deRochemonteix, B. Burrus, S. Demczuk, and C. A. Dinarello. 1986. Human recombinant interleukin 1 stimulates collagenase and prostaglandin $\mathrm{E}_{2}$ production by human synovial cells. J. Clin. Invest. 77:645-648.

10. Dayer, J.-M., B. Beutler, and A. Cerami. 1985. Cachectin/tumor necrosis factor exerts endocrine, paracrine, and autocrine control of inflammatory responses. J. Exp. Med. 162:2163-2168.

11. Firestein, G. S., J. M. Alvaro-Gracia, and R. Maki. 1990. Quantitative analysis of cytokine gene expression in rheumatoid arthritis. J. Immunol. 144:3347-3353.

12. Firestein, G. S. 1991. The immunopathogenesis of rheumatoid arthritis. Curr. Opin. Rheumatol. 3:398-406.

13. Firestein, G. S., and N. J. Zvaifler. 1990. How important are T cells in chronic rheumatoid synovitis? Arthritis Rheum. 33:768-773.

14. Alvaro-Gracia, J. M., N. J. Zvaifler, C. B. Brown, K. Kaushansky, and G. S. Firestein. 1991. Analysis of the synovial cells involved in granulocytemacrophage colony stimulating factor production and gene expression in rheu- 
matoid arthritis and its regulation by IL-1 and tumor necrosis factor- $\alpha$. J. Immunol. 146:3365-3371.

15. Alvaro-Gracia, J. M., N. J. Zvaifler, and G. S. Firestein. 1989. Cytokines in chronic inflammatory arthritis. J. Exp. Med. 170:865-875.

16. Koch, A. E., P. J. Polverini, and S. J. Leibovich. 1986. Stimulation of neovascularization by human rheumatoid synovial tissue macrophages. Arthritis Rheum. 29:471-479.

17. Koch, A. E., S. J. Leibovich, and P. J. Polverini. 1988. Functional heterogeneity of human rheumatoid synovial tissue macrophages. J. Rheum. 15:10581063.

18. Koch, A. E., J. C. Burrows, G. K. Haines, T. M. Carlos, J. Harlan, and S. J. Leibovich. 1991. Immunolocalization of leukocyte and endothelial adhesion molecules in human rheumatoid and osteoarthritic synovial tissues. Lab. Invest. 64:313-320.

19. Carlos, T., and J. M. Harlan. 1990. Membrane proteins involved phagocyte adherence to endothelium. Immunol. Rev. 114:1-28.

20. Yoshimura, T., E. A. Robinson, S. Tanaka, E. Appella, and E. J. Leonard. 1989. Purification and amino acid analysis of two human monocyte chemotractants produced by phytohemaglutinin-stimulated human blood mononuclear leukocytes. J. Immunol. 142:1956-1962.

21. Furutani, Y., H. N. Nomura, M. Notake, Y. Oyamada, T. Fukui, M. Yamada, C. G. Larsen, J. J. Oppenheim, and K. Matsushima. 1989. Cloning and sequencing of the cDNA for human monocyte chemoattractant and activating factor (MCAF). Biochem. Biophys. Res. Commun. 159:249-255.

22. Yoshimura, T., E. A. Robinson, S. Tanaka, E. Appella, and E. J. Leonard. 1989. Purification and amino acid analysis of two human glioma-derived cytokines. J. Exp. Med. 169:1449-1459.

23. Matsushima, K., C. G. Larsen, G. C. DuBois, and J. J. Openheim. 1989. Purification and characterization of a novel monocyte chemotactic and activating factor produced by a human myelomonocyte cell line. J. Exp. Med. 169:1484-1490.

24. Streiter, R. M., R. Wiggins, S. H. Phan, B. L. Wharram, H. J. Showell, D. G. Remick, S. W. Chensue, and S. L. Kunkel. 1989. Monocyte chemotactic protein gene expression by cytokine-treated human fibroblasts and endothelia cells. Biochem. Biophys. Res. Commun. 162:694-700.

25. Sica, A., J. M. Wang, F. Colotta, E. Dejana, A. Mantovani, J. J. Oppenheim, C. G. Larsen, C. O. Zachariae, and K. Matushima. 1990. Monocyte chemotactic and activating factor gene expression induced in endothelial cells by IL-1 and tumor necrosis factor. J. Immunol. 144:3034-3038.

26. Larsen, G. C., C. O. Zachariae, J. J. Oppenheim, and K. Matsushima. 1989. Production of monocyte chemotactic and activating factor (MCAF) by human dermal fibroblasts in response to interleukin-1 or tumor necrosis factor Biochem. Biophys. Res. Commun. 160:1403-1408.

27. Yoshimura, T., and E. J. Leonard. 1990. Secretion by human fibroblasts of monocyte chemoattractant protein-1, the product of gene JE. J. Immunol. 144:2377-2383.

28. Graves, D. T., Y. L. Jiang, M. J. Williamson, and A. J. Valente. 1989. Identification of monocyte chemotactic activity produced by malignant cells. Science (Wash. DC). 245:1490-1493.

29. Elner, S. G., R. M. Streiter, V. M. Elner, B. J. Rollins, M. A. Del Monte, and S. L. Kunkel. 1991. Monocyte chemotactic protein gene expression by cytokine treated human retinal pigment epithelial cells. Lab. Invest. 64:819-825.

30. Rollins, B. J., P. Stier, T. Ernst, and G. G. Wong. 1989. The human homolog of the JE gene encodes a monocyte secretory protein. Mol. Cell. Biol. 9:4687-4695

31. Rollins, B. J., T. Yoshimura, E. J. Leonard, and J. S. Pober. 1990. Cytokine-activated human endothelial cells synthesize and secrete a monocyte chemoattractant, MCP-1/JE. Am. J. Pathol. 136:1229-1233.

32. Arnett, F. C., S. M. Edworthy, D. A. Bloch, D. J. McShane, J. F. Fries, N. S. Cooper, L. A. Healey, S. R. Kaplan, M. H. Liang, H. S. Luthra, et al. 1988 The American Rheumatism Association 1987 revised criteria for the classification of rheumatoid arthritis. Arthritis Rheum. 31:315-324.

33. Altman, R., E. Asch, D. Bloch, G. Bole, D. Borenstein, K. Brandt, W Christy, T. D. Cooke, R. Greenwald, and M. Hochberg. 1986. Development of criteria for the classification and reporting of osteoarthritis: classification of osteoarthritis of the knee. Arthritis Rheum. 29:1039-1049.

34. Koch, A. E., J. C. Burrows, A. Skoutelis, R. Marder, P. Domer, and S. J. Leibovich. 1991. Monoclonal antibodies detecting monocyte/macrophage activation and differentiation antigens and identifying functionally distinct subpopulations of human rheumatoid synovial tissue macrophages. Am. J. Pathol. 138:165-173.

35. Koch, A. E., P. J. Polverini, and S. J. Leibovich. 1986. Induction of neovascularization by activated human monocytes. J. Leukocyte Biol. 39:233238.

36. Evanoff, H. L., M. D. Burdick, S. A. Moore, S. L. Kunkel, and R. M. Streiter. 1992. A sensitive ELISA for the detection of human monocyte chemoattractant protein-1 (MCP-1). Immunol. Invest. 21:39-45.

37. Standiford, T. J., S. L. Kunkel, M. A. Basha, S. W. Chensue, J. P. Lynch III, G. P. Toews, J. Westwick, and R. M. Strieter. 1990. Interleukin-8 gene expression by a pulmonary epithelial cell line: a model for cytokine networks in the lung. J. Clin. Invest. 86:1945-1953.

38. Chirgwin, J. M., A. E. Przybyca, R. J. MacDonald, and W. J. Rutter. 1979. Isolation of biologically active ribonucleic acid from sources enriched in ribonuclease. Biochemistry. 18:5294-5299.

39. Jonas, E., T. D. Sargent, and I. B. Davis. 1985. Epidermal keratin gene expressed in embryos of xenopus laevis. Proc. Natl. Acad. Sci. USA. 82:54135416.

40. Koch, A. E., G. K. Haines, R. Rizzo, J. A. Radosevich, R. M. Pope, P. G. Robinson, and W. H. Pearce. 1990. Human abdominal aortic aneurysms: immunophenotypic analysis suggesting an immune-mediated response. $A m . J$. Pathol. 137:1199-1213.

41. Robinson, P. G., E. W. Eggena, A. E. Koch, and J. A. Radosevich. 1989. A method for immunohistochemical staining with an iron counterstain. Lab. Med. 20:569-571.

42. Hsu, S. M., L. Raine, and H. Fanger. 1981. Use of avidin-biotin-peroxidase complex $(\mathrm{ABC})$ in immunoperoxidase techniques: a comparison between ABC with unlabeled antibody (PAP) procedures. J. Histochem. Cytochem. 29:577-580.

43. Koch, A. E., J. A. Radosevich, P. G. Robinson, and R. M. Pope 1990 Distribution of CD45RA+ and CD45RO+ T lymphocyte subsets in rheumatoid arthritis synovial tissue. J. Clin. Immunol. 10:192-199.

44. Koch, A. E., J. C. Burrows, R. M. Marder, P. Domer, and S. J. Leibovich. 1990. Reactivity of human tissues with monoclonal antibodies to myeloid activation and differentiation antigens. Pathobiology. 58:241-248.

45. Winer, B. J. 1971. Statistical principles in experimental design. McGrawHill Inc., New York.

46. Carmer, S. G., and M. R. Swanson. 1973. An evaluation of ten pairwise multiple comparison procedures by Monte Carlo methods. J. Am. Stat. Assoc. 68:66-74.

47. Matsushima, K., and J. J. Oppenheim. 1989. Interleukin-8 and MCAF: novel inflammatory cytokines inducible by IL-1 and TNF. Cytokines. 1:2-13.

48. Schall, T. J. 1991. Biology of the RANTES/SIS cytokine family. Cytokines. 3:165-183.

49. Verghese, M. W., and R. Snyderman. 1989. Chemotaxis and chemotactic factors. In Human Monocytes. M. Zembala and G. L. Asherton, editors. Academic Press Inc., San Diego, CA. 167-175.

50. Harris, E. D. 1988. Pathogenesis of rheumatoid arthritis: a disorder associated with dysfunctional immunoregulation. In Inflammation: Basic Principles and Clinical Correlates. J. I. Gallin, I. M. Goldstein, and R. Snyderman, editors. Raven Press, Ltd., New York. 751-773.

51. DeMarco, D., S. L. Kunkel, R. M. Streiter, M. Basha, and R. B. Zurier 1991. Interleukin-1 induced gene expression of neutrophil activating protein (interleukin-8) and monocyte chemotactic peptide in human synovial cells. Biochem. Biophys. Res. Commun. 174:411-416.

52. Streiter, R. M., S. W. Chensue, M. A. Basha, T. J. Standiford, J. P. Lynch III, M. Baggiolini, and S. L. Kunkel. 1990. Human alveolar macrophage gene expression of interleukin- 8 by tumor necrosis factor- $\alpha$, lipopolysaccharide, and interleukin-1 13. Am. J. Respir. Cell Mol. Biol. 2:321-326. 